\title{
Serjeant Musgrave's disease
}

\section{G E Langley}

J Med Ethics; Medical Humanities 2004;30:74-78. doi: 10.1136/jmh.2004.000180

The present title takes a liberty with the title of playwright John Arden's Serjeant Musgrave's Dance, but not with the text. Toward the end of the play, Serjeant Musgrave exclaims "There used to be my duty: now there's a disease". So what is the serjeant's "disease"? The play, subtitled "an unhistoric parable" is a commentary on an unspecified late 19th century war in a British protectorate as experienced by four soldiers, now returned to England and visiting a North country colliery town, ostensibly to recruit, but with a deeper motive not initially apparent. Readers of Medical Humanities will know that the arts hold more for doctors than direct clinical relevance, and this play is no exception. There is a powerful account, not inappropriate at the present time, of the disruptive effects of war and violence on the soldiers involved, their families, and the civilian populations. War is contrasted with the industrial unrest in the local colliery. My present concern is to examine Serieant Musgrave's mental state, and the dynamics within his band.

Correspondence to:

G E Langley,

Hanningtields,

Warborough Hill, Kenton

Exeter, Devon, EX6 8LR;

langleygd@eclipse.co.uk

Accepted for publication 22 September 2004
D ance-attendance on: do one's utmost to please someone by attending to all their needs. ${ }^{1}$

Dance-to someone's tune: comply completely with someone's demands and wishes. ${ }^{1}$

Dance of Death-medieval allegory in which a personified Death leads all to the grave.

Parable-a story with "a moral or spiritual value".

Sergeant Musgrave's Dance achieves much of its dramatic effect by unfolding the story almost in reverse order. ${ }^{2} \dagger$

This is not helpful to clinical analysis and events will now be told in the sequence that they occurred. Those who have not read the play already and who wish to share its drama should "look away now", and read the play. Firstly, the personalities of the four soldiers will be described, and secondly, their story. In both cases the information is derived from the author's own introduction and the play's text.

\section{THE SOLDIERS (BEFORE THEIR CRISIS)}

Serjeant Musgrave is sardonic, commanding, and never humorous. He is punctual, disciplined, protective of his men, and governed by a sense of duty, to both the Queen's regulations and the Bible. For eighteen years he has saluted the flag and "danced beneath it".

He is a hard man who has killed in the line of duty but has been comforted by prayer (his religion is implicitly "Old Testament"). He has pride in his work and equipment. His duty is his life; to lay it down for his Queen, for peace, and for honesty.

Attercliffe is in his 50s, and is the senior "other rank". He is embittered but has served loyally and still thinks well of his wife, although, in his absence, she deserted him for a grocer. He is a moderating influence on the others.

Hurst is in his 20s and is aggressive, quick tempered, tough, cynical, and not as bright as he thinks he is. He can be violent.

Sparky is young. He is immature, easily led, fond of cards and singing, and hides behind his clowning.

Billy Hicks does not appear as a living character in the play. His story is told by others. Before joining up he was a cheerful and musical young man who lived in the colliery town in which the play is set. The landlady of his "local" remembers that he would get "pissed on a Saturday night" and sing hymns in the bar. To her he was "not a bad young feller...but he weren't no good neither" (I.ii.26). While drunk he is enlisted by a recruiting party and on departure leaves behind his girlfriend, Annie, the local barmaid, who, unbeknown to Billy bears and loses his child.

\section{THE STORY}

Billy and the four soldiers serve overseas in a British protectorate. He is well liked by his comrades. While stationed in a town in the protectorate, Billy follows his interest in music, breaks a curfew, and attends the local opera. Returning to his unit he is shot in the back by "antiBritish subversives" and killed, the latest, in recent weeks, of 15 similar killings. The soldiers are incensed- "they didn't dare shoot him to his face" - and his regiment, including Serjeant Musgrave and his squad, are turned out, late at night, to find the killers, with orders that there are to be "no undue measures, minimum violence" .

No killers are found, but control is loosened, houses are entered, and fifteen civilians are injured and five killed. At one point Serjeant Musgrave, in command, threatens to open fire on civilians (but it is not clear whether he did so). This, more than Billy's death, leads him to a personal crisis about soldiering (see below). He steals money, and weapons, and with Billy's body and three companions returns to Billy Hicks's home town. On the road Hurst has

Abbreviations: PSTD, post traumatic stress disorder

†Page references throughout the paper are to this 1982 Methuen student edition of the play. 
joined the deserters to escape punishment for shooting his officer. Attercliffe is turned against soldiering, like Musgrave, by the events of the night. Sparky, upset by losing his mate Billy, was drunk and AWOL for four days and after arrest was placed in Musgrave's custody. He deserts with him when promised that he will be shown how Billy "can be paid for".

Musgrave's mission is to preach against war- "Let the word dance...God's dance". In Billy's town they find the colliers on strike (or being locked out depending on viewpoint). The soldiers say they are recruiting, but there is suspicion that they are there to break the strike. As the town is cut off by inclement weather they spend an evening in the pub making friends with local officials and colliers. When the constable, on orders from the mayor, tries to close the pub early, they become truculent and are called to order by Musgrave. Sparky makes a pass at Annie who refuses him. After some drunken fooling in the street, they all go off to bed (but are all still seen on stage). Sparky is annoyed with Hurst, his rival, for securing a visit from Annie. When she arrives Hurst rejects her. She turns to Attercliffe but he breaks away after kissing her, driving Annie to tears. Sparky is afraid for his future and talks to Annie about the two of them leaving together that night. As Sparky is dressing to go Hurst interrupts, seizes Sparky's trousers, and accuses him of deserting. A fight follows, Attercliffe intervenes, Hurst grabs Sparky's bayonet and in a general melee Sparky is killed, probably accidentally, but nevertheless as a consequence of anger. While this has been happening Musgrave wakens from a bad dream in considerable distress and appears to be reliving his engagement with the civilians in the protectorate. He then joins his companions and tells them to hide Sparky's body Noises off indicate an abortive attempt by colliers to steal their machine-gun. Alarmed at the threat to civil order the mayor and constable telegraph for a detachment of dragoons to come the next day when, in spite of Sparky's death, Musgrave persuades Hurst and Attercliffe to hold a recruiting meeting.

Early in the morning the mayor (who is also the colliery owner), the parson, and the constable gather, together with the colliers and Musgrave's men, in the town square. The mayor and parson speak in favour of recruitment, the former offering gold to those that join. Musgrave tells them there is more to army life than over zealous NCOs and speaks with pride about the real army, demonstrating, as he does so, a rifle and the gatling (machine) gun. Increasingly tense, he speaks of the effective use of the weapons on the Russians in Crimea,- - but notes that there is no longer war with France or Germany and that at the time of the incident, they were in a protectorate flying the British flag. He says: "A soldier's life is to lay it down against the enemies of the Queen...for peace and for honesty". Becoming more passionate he tells with pride of serving the flag from morning onwards for 18 years, but suddenly asks on a pessimistic note: “...can you haul it [the flag] down at dark?" The last of their packing cases is then opened, revealing a soldier's skeleton that they hang from a street lamp. Musgrave dances and sings: "Up he goes and no one knows, How to bring him downwards", but he does not immediately reveal the skeleton as that of Billy.

There is general consternation, the mayor accusing Musgrave of being "balmy (sic), mad, stark of his nut". To prevent the crowd from leaving Musgrave threatens all with the gatling gun and tells them how the man died, still without revealing his identity. He holds responsible not only the colonial population but also the break down of order. A collier comments that after enlisting "you deserve all you

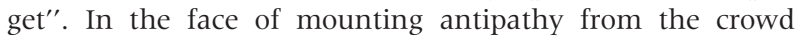
Musgrave finally tells them that the skeleton is that of their townsman, Billy Hicks (III.i.89). He tries to justify his actions in "the causes of the Almighty in every human work"
(III.i.90) and elaborates his earlier belief, that Billy was killed because of circular mounting violence between the army and the locals, a situation that he thinks will recur unless remedied. Having lived for 18 years by the Queen's book he is: "now turned inside out. There used to be my duty: now there is a disease" (III.i.90).

A collier asks: "can we go home?" Musgrave muses that in retribution: " 25 persons will have to be killed today" (III.i.91) and appeals for help. Attercliffe protests that Musgrave cannot effect a "cure" and reminds him that he had sworn that there would be no killing (page 93). Musgrave denies it and becomes angrier. Attercliffe, then manning the gatling gun, has had enough, and stands away (III.i.93) but the aggressive Hurst takes his place, later handing the gun over to a civilian, the rogue bargee. Hurst tells the crowd that the soldiers came back "to show... what it's like to earn a living by beating and killing" and asks: "Should we start with the civic officers?" Annie, however, tells of Sparky's death, the crowd become alienated and Hurst, facing, as he sees it, defeat, retakes the gun and threatens, in retribution, to shoot, not the colliers, but those higher up. He likens his threats to action taken abroad and cries: "We've earned our living by beating and killing folk like yourselves in the streets of their own city". Musgrave, despite his earlier threats, physically stops Hurst from shooting. In anger Hurst takes a rifle and says that he is leaving. As he goes he is shot and killed by dragoons appearing from offstage. Musgrave is identified by the dragoons and, with Attercliffe, is arrested.

The final scene is in prison. Attercliffe tries to comfort Musgrave. The publican, Mrs Hitchcock brings refreshment which Musgrave refuses, saying: "Numbers and order. According to Logic. I had it worked out for months. What made it break down" III.ii.101. Mrs Hitchcock implies it was Sparky's death. Musgrave says that it was accidental, but neither Attercliffe nor Mrs Hitchcock agrees. Musgrave reiterates "Good order and discipline: it's the only road I know" but Mrs Hitchcock accuses him of bringing anarchy instead of "life and love" and separates the colliery dispute from an act of war. Attercliffe sides with Mrs Hitchcock in believing that Musgrave's method of trying to end war was wrong. "You can't cure pox by whoring", he says. Musgrave again denies it and asserts: "God was with me" ending, disconnectedly, "... and all they dancing-all of themthere". Mrs Hitchcock responds: "But it's not a dance of joy". The play ends with a sad song from Attercliffe, whose closing words are: "They're going to hang us up a length higher nor most apple trees grow, Serjeant. Do you reckon we can start an orchard?" (III.ii.101)

\section{INTERPRETATION}

This clinical analysis deals with Musgrave's "disease" together with some mention of his men, but leaves aside the broader issues of war and the colliery strike.

\section{General}

The emotional consequences of catastrophe and war have been known from time immemorial but psychiatric analysis is a comparatively recent development. That is not to say that emotional reactions to crisis did not antedate their professional description and clinical classification. Beveridge ${ }^{3}$ describes how Charles Dickens was involved in a serious rail accident and reported, a year later, "sudden vague rushes of terror even when riding in a Hansom Cab". Nineteenth century neurologists described post traumatic "railway spine" but psychiatry was little concerned until brief mention of "traumatic neurasthenia" in Tuke's 1892 Dictionary of Psychological Medicine (Beveridge, ${ }^{3}$ p 6). ${ }^{45}$ The first world war produced "shell shock", with emphasis on constitutional predisposition and organic cause. Gersons and Carlier ${ }^{6}$ noted 
that the changes were even attributed by some to "microsections of exploded bomb having entered the brain". After the second world war the reference manual DSM-I ${ }^{7}$ coined "battle fatigue" and "gross stress reaction" with the recognition that even the most robust could suffer. Deahl ${ }^{8}$ describes how the Korean war produced its own mental aftereffects, including substance abuse, but these reactions were not studied intensively.

It was not until the Vietnam War of 1964-75 that the continued aftereffects of combat (as opposed to immediate reactions-battle shock or acute combat stress reaction) was studied. Post traumatic stress disorder (PTSD) then appeared for the first time as an entity and as a diagnosis in the revised DSMIII, ${ }^{9}$ and was elaborated upon through to DSM-IV ${ }^{10-12}$ and connected with non-combatant forms of trauma, such as the capsize of the car ferry, The Herald of Free Enterprise.

In the light of this chronology it is notable that John Arden, in 1960, portrays symptoms of post traumatic stress disorder long before they became a recognised diagnostic entity in 1980 - but not before the condition existed. My own interest in combat stress spans a period from the summer of 1951 when I was regimental medical officer on active service in Korea with the 1st Battalion Royal Northumberland Fusiliers (29 Independent Infantry Brigade) to the 1990s when I worked on war pension assessments. Service interest in 1951 centred on the immediate effect of fear in battle, the early management of such psychological distress, and early return to active duties. Although any active service has its moments I cannot claim any personal experience of extreme trauma but have met many who did and who survived. A small minority showed immediate crippling anxiety. Later, contact with regimental comrades has brought to my notice enduring examples of what would now be called PTSD. Without wishing to be too explicit I am aware of the effect of combat on those who experienced physical injury, subsequent isolation, and rescue only after an indeterminate delay. Subsequent PTSD has led to family distress and the need for psychotherapeutic re-enactment. During the 1990s my experience in assessing war pension claimants brought to my notice active cases of PTSD dating from the second world war, through Northern Ireland, and on to the Falklands. With this background the impact of attending a performance of "Serjeant Musgrave" was powerful, although unexpected.

The essential features of PTSD, as described in DSM-IV, ${ }^{10}$ are now considered in turn in the light of Sjt Musgrave's behaviour.

\section{Does Musgrave fit the pattern of PTSD? The trauma}

The American Psychiatric Association's Diagnostic and Statistical Manual IV lists as necessary for making the diagnosis: exposure to actual or threatened death or serious injury in self or others and a response that involved fear, helplessness or horror. Rather than extreme battle trauma, Musgrave's regiment had been exposed to persistent and insidious threat from the civilian population-three soldiers shot that week, including Billy, and fifteen in a month. Musgrave felt horror at "a colonial war of sin and unjust blood" in which twenty five men and nine women (one allegedly a child) were killed or seriously injured in a revenge action by troops. He smarted about "dishonour and greed" arising from action that caused the civilian injuries and deaths ( 1.iii.36-7; II.ii.64). He had indeed experienced "death or serious injury" to "self or others" and particularly a "fear or helplessness" arising from isolation and his position of command. He illustrates this burden by using a parade ground analogy. "You are right-marker for the Company, you are marching and can't see the others. You can only follow orders and hope that you hear them". Once, however, in training, he had misheard and to his embarrassment, had finished up separated from the squad (II.iii.65). In the protectorate he threatens to fire but the text leaves doubt as to whether the order was given or not. The decision was his, and his alone. His later dreams suggest an agony of mind at this moment over a conflict between his duty and his revulsion at the extent of the violence. Finally, in the here and now of the play, he has to cope with the death of yet another comrade, Sparky.

\section{Re-experience}

The Diagnostic and Statistical Manual IV lists the following: The event is persistently re-experienced, there are intrusive thoughts or images, and recurrent distressing dreams. Actions or feeling may make it appear as if the traumatic event is recurring. Intense psychological distress on exposure to symbolic cues can result in physiological overactivity.

Re-experience of the event is seen vividly in Musgrave's tormented dreaming and cries (II.ii.64).

"Burning, burning... you carry out your orders. ... I'm timing the end of the world. Five, three, two, one". He lets out a cry of anguish and falls back on the bed

At the height of his distress and at the critical moment of ordering "fire" he appears to repress the memory and be "on duty". In his later "recruiting" speech (III.i.84) he becomes more and more emotional as he tells the story. The skeleton becomes his flag and towards the end he seems to be re-living the trauma (III.i.86-90). He threatens local officers with retribution (III.i.91-2) whom he (unreasonably) holds responsible, in spite of his insistence on "logic".

\section{Avoidance}

The Diagnostic and Statistical Manual IV lists: persistent avoidance of associated stimuli (three or more) and numbing of general responsiveness; efforts to avoid associations, activities, places, and people; inability to recall; diminished participation in significant activities; feeling detached and estranged; restricted affective range (inability to love), and a sense of a foreshortening future.

The whole desertion can be seen as avoidance. Early in the play (1.ii.26-7) Musgrave discusses Billy with Mrs Hitchcock "without emotion" (numbing). Before his dreams the trauma is not discussed. His memory of the firing is hazy and when he is fully awake he does not again mention the shooting (II.iii.65). Apart from his final outburst his affect is restricted. His solution, "logic", denies feeling. At one point in act I, in dialogue with Hurst, he anticipates Hurst being hanged (I.iii.29), but he himself is more idealistic if not fatalistic "God, my Lord God...make this dance as terrible as You have put it into my brain. The Word alone is terrible: the deed must be worse. But I know it is Your Logic, and You will provide" (I.iii.37). After arrest Attercliffe has to remind him that, notwithstanding "Numbers \& order. According to logic" (III.ii.101) they are both to be hanged. At this stage he cannot empathise with Mrs Hitchcock's account "of life \& love in the town"-another possible example of numbing.

\section{Arousal}

The Diagnostic and Statistical Manual IV lists: persistent increased arousal (with two or more of): difficulty in falling asleep; irritable or angry outbursts; poor concentration, hypervigilance, and marked startle responses.

Musgrave shows both sleep disturbances (II.iii.64-5) and irritability (III.i.93). By the end of his "dancing" speech he is described as "at the top of his passion". In prison he is despondent but still seeking comfort in numbers and logic. When criticised by Mrs Hitchcock he angrily asserts he was doing his duty. 


\section{Duration and social effect}

The Diagnostic and Statistical Manual IV lists: duration more than one month and clinically significant impairment in social and occupational functions.

It would take longer than one month to get back from the colony. The effect on social integration has been severe. Musgrave has lost his lifelong regimental affiliations, he is on the run in his own country and then rapidly loses the good will of his fellow soldiers and the community that he set out to turn against colonial warfare.

The information available from the play does not meet the exacting diagnostic standards of Newman \& Lee, ${ }^{11}$ who require a full developmental history and examination, with or without semistructured interviews and questionnaires. Nevertheless allowance must be made for dramatic licence and it is asserted that on the evidence provided in the play Sjt Musgrave can be diagnosed as suffering from PTSD. If this is accepted then the play gives some further insights into mechanisms operating within this condition.

\section{PSYCHIC RESPONSES TO TRAUMA}

Parkes, ${ }^{13}$ in a developmental approach to understanding responses to stress, describes three overlapping systems: responses to: (i) threat, (ii) separation, and (iii) change. Threat has already been discussed and separation will be addressed later. The third, change, is particularly significant in the case of Musgrave who, as described by Parkes, has, within his mind, and like all of us, a well established complex "assumptive model" that is activated in everyday responses to challenge. For Musgrave it has been formed over 18 years of duty, "dancing below the Queen's flag" (iii.I.84). His military model is then challenged by a traumatic experience (III.i.90), and he passionately denounces all that he has lived by for so long:

"It [the Queen's book] turned inside out for me (italicised in text). There used to be my duty now there is a disease. Wild wood mad we are."

Elsewhere he has made it clear that it is not all wars about which he protests, just his recent colonial experience. His sense of duty remains but he is now tortured by the conflict between duty and guilt at the action that he has taken against civilians. Parkes describes two intrapsychic defences in the face of such conflict. Firstly, the old world is idealised-the subject refuses to accept change and in this case remains locked in a no longer relevant set of military assumptions about duty. Secondly, the new world is idealised. Musgrave turns his back on his idealised past and embraces his new campaign against war with uncritical enthusiasm. When this remaining defence is challenged (III.i.92.) he becomes angry and threatening.

\section{COGNITIVE MECHANISMS}

As already noted, at one point, waking from his dream, Musgrave counts down in his memory of ordering fire and stops at a moment of anguish as if he cannot, or does not wish to, remember what followed (II.iii.64). He then speaks to Mrs Hitchcock about the end of the world without explicit recall of the earlier moment. Later (III.i.86-90) his memory is quite explicit.

Two memory mechanisms are described as operating in PTSD by Siegal. ${ }^{14}$ Explicit memory is the common experience of recalling past events and many examples occur in the play. Implicit memory, however, involves different neural pathways, is used in acquiring skills and in conditioning, and is expressed through performance rather than recall. At the time of acute trauma the explicit pathways are overwhelmed. Rather than memories being processed by explicit pathways and consolidated into narrative, memories are processed by implicit pathways. They remain in cruder form with a tendency to recur as intrusions or traumatic re-enactments when triggered by perception, symbolic stimuli, or emotional states. Musgrave's tension increases in act III as he recalls the colonial civil unrest and is faced by opposition from the colliers and his own men. One moment he is the proud "Black Jack Musgrave" (III.i.84) and moments later he speaks of his duty in the past tense and of his present "disease". In the face of opposition he progresses from revulsion to revenge and considers killing the colliery town's people. At this time he seems to be operating on implicit memory, as if living in the colonial town. This is an abrupt "state of mind shift" as described in PTSD. Such shifts may not make sense to those who experience them and may be attributed to different "selves" (Siegal, ${ }^{14}$ p 47). Musgrave's sudden shift to wishing to kill (III.i.91-2) illustrates this mechanism. Cognitive behavioural models of PTSD similarly include responses "conditioned" by the original trauma and later augmented by generalisation of the stimuli beyond those originally present-for example, in this case responding to the colliers as if they were the colonials.

\section{PSYCHOANALYTIC MODELS OF PTSD}

Velsen $^{15}$ says that while initially, psychoanalytic models of PTSD concentrated on early intrapsychic traumas, more recent interest balances this with greater attention to the current life stresses. Not everyone who experiences trauma develops PTSD, a fact that may be linked to early life experiences and biological disposition, see Lee \& Turner. ${ }^{16}$ No indication is given in the play about the early life history of the soldiers which could throw any light on why they themselves, rather than others, suffered as they did, but this is not to deny the potential of such factors.

\section{BEREAVEMENT THEMES}

Billy Hicks was a comrade lost, and a comrade mourned, particularly by Sparky in the four days immediately after the loss (I.iii.34). Traumatic stress and mourning the loss of a comrade are evoked by separate stimuli, each with its own characteristic pattern of sequelae. Raphael ${ }^{17}$ points out that when both stimuli are present, the avoidance mechanisms of PTSD may block the normal course of mourning. Preoccupation with, and repetitive memories of, the deceased are well recognised features of mourning. They are certainly seen in Musgrave and his men, although bringing along the deceased's body, transformed into a skeleton, even allowing for dramatic licence, is an extreme expression! This aside, Musgrave's energetic mission can also be seen as a sublimatory flight into activity as part of his grieving. Grief is seen early on (I.iii.29) when Musgrave foresees Hurst being hanged, and tells Sparky "You've got grief" (I.iii.35). Finally, in a cell, Musgrave is not surprisingly morose. In these soldiers, trauma and bereavement stimuli have overlapped and as suggested above their capacity to grieve may have been diminished. A further interpretation is that the whole of their desertion and subsequent behaviour, knowing that they would be called to task, formed a depressive symbolic suicide.

Two other interesting incidents are possibly related to mourning, Firstly, when Hurst is incensed with Sparky for wishing to leave with Annie (II.iii.67) he calls him a deserter. As they all are deserters this is a curious accusation and must arise from some other feeling. Similarly when Hurst wants to leave Musgrave frantically calls him back (III.i.97). What seems to be happening is that in their stressful flight they have bonded as "buddies", a known and cultivated support phenomena in the services. It is attempts to breach these "buddy bonds" that evoke protest from their comrades. Thus in crisis their stress is even more heightened. The loss of a "buddy" is worse than the loss of someone more distant. 
Unrecognised in Musgrave's time, and formally even when the play was written, Musgrave's anguish led him to liken it to a disease, and to behaviour for which he was punished rather than helped. Present day students of psychological trauma may gain both humanity and therapeutic insights from this play where "Dance" in many senses is personified-attendance upon military duty, dance to the military tune, and, in the end, the dance of death.

Dr Langley is a retired consultant psychiatrist.

\section{REFERENCES}

1 Speke J, ed. Oxford dictionary of idioms. Oxford: Oxford University Press, 1999.

2 Arden J. Serjeant Musgrave's dance, an unhistorical parable. London: Methuen, 1982

3 Beveridge A. On the origins of post traumatic stress disorder. In: Black D, Newman M, Harris-Hendricks J, et al, eds. Psychological trauma, a developmental approach. London: Gaskell, 1997:3-9.

4 Friedman MJ. A brief history of the PTSD diagnosis www.ncptsd.org/facts/ general/fs_overview.html (accessed 3 Oct 2004).

5 Jones $\mathrm{E}$, Wesley S. Psychiatric battle casualties: an intra- and inter- war comparison. Br J Psychiatry 2001;178:242-7.

6 Gersons BPR, Carlier IVE. Post traumatic stress disorder: the history of a recent concept. Br J Psychiatry 1992;161:742-8.

7 American Psychiatric Association. Diagnostic and statistical manual i. Washington DC: APA, 1952.
8 Deahl M. The effect of conflict on combatants. In: Black D, Newman M, HarrisHendricks J, et al, eds. Psychological trauma, a developmental approach. London: Gaskell, 1997:134-47.

9 American Psychiatric Association. Diagnostic and statistical manual iii. Washington DC: APA, 1980

10 American Psychiatric Association. Diagnostic and statistical manual iv. Washington DC: APA, 1994

11 Newman $M$, Lee D. Diagnosis \& treatment: a diagnosis. In: Black D Newman M, Harris-Hendricks J, et al, eds. Psychological trauma, a developmental approach. London: Gaskell, 1997:219-29.

12 Turnbull G. Classification. In: Black D, Newman M, Harris-Hendricks J, et al, eds. Psychological trauma, a developmental approach. London: Gaskell, 1997:19-30.

13 Parkes CM. Normal and abnormal responses to stress: a developmental approach. In: Black D, Newman M, Harris-Hendricks J, et al, eds. Psychological trauma, a developmental approach. London: Gaskell, 1997:10-18.

14 Siegal D. Memory and trauma. In: Black D, Newman M, Harris-Hendricks J, et al, eds. Psychological trauma, a developmental approach. London: Gaskell, 1997:44-53.

15 Van Velsen C. Theoretical models-psychoanalytic. In: Black D, Newman M, Harris-Hendricks J, et al, eds. Psychological trauma, a developmental approach. London: Gaskell, 1997:61-3.

16 Lee D, Turner S. Theoretical models - cognitive behavioural.

In: Black D, Newman M, Harris-Hendricks J, et al, eds. Psychological trauma, a developmental approach. London: Gaskell, 1997:64-77.

17 Raphael B. The interaction of trauma and grief. In: Black D, Newman M, Harris-Hendricks J, et al, eds. Psychological trauma, a developmental approach. London: Gaskell, 1997:31-43. 